\title{
POLYGAMY AGAINST MORAL OR AGAINST LAW? A COMPARATIVE STUDY BETWEEN BRAZILIAN LAW AND ISLAMIC LAW
}

\author{
POLIGAMIA CONTRA A MORAL OU CONTRA O DIREITO? UM \\ ESTUDO COMPARADO ENTRE O DIREITO BRASILEIRO E O \\ DIREITO ISLAMMICO
}

\author{
Bárbara Mendonça Bertotti ${ }^{1}$ \\ Cynthia Gruendling Juruena ${ }^{1}$ \\ Mohamed A. 'Arafa'
}

Recebido em: 05/06/2020 Aceito em: 27/07/2021

barbarabmmab@gmail.com cjuruena@gmail.com marafa@iupui.edu

\begin{abstract}
This article aims to investigate in a different way the concomitant relations of conjugality - here from the moment it is formalized matrimonialized as to its conformation as a situation of fact, not Authorized and not Islamic Law. The Brazilian and Islamic legal systems admit and protect polygamous relationships? The conclusion is that the right of reply is the right of police expression manifested in polygamy. In Brazil, the laws are not of the world of facts, being inclusive, in some cases, those of the right to the right, but there is still a strong tendency to legalize the legalization of polygamy, for strictly moral/religious reasons. Thus, contrary to common sense, the study concluded that the Muslim is more monogamous than the Brazilian is. Still, it can be affirmed that, although Brazil declares itself secular, in practice there is no demarcated separation between State and religion. The Islamic communism is the rights of human religion. Paradoxically, would Brazil then be cloaked in the veil of Islam? The methodology used is exploratory, from a comparative perspective, taking the necessary precautions to differentiate between the two systems.
\end{abstract}

Keywords: polygamy; Islamic law; Brazil; morality; religion.

Resumo: O presente artigo objetiva examinar a apreensão jurídica e atribuição de eficácia de duas ou mais relações concomitantes de conjugalidade - aqui tomada tanto em sua concepção formal matrimonializada quanto em sua conformação como situação de fato, no Direito brasileiro e no Direito islâmico. Em outras palavras: os sistemas jurídicos brasileiro e islâmico admitem e tutelam relações poligâmicas? A conclusão a que se chega é que, em que pese o Direito islâmico expressamente permitir o casamento poligâmico, na prática há poucas situações de poligamia. Já no Brasil, essas relações existem no mundo dos fatos (e não são poucas), sendo inclusive, em alguns casos, tuteladas pelo Direito, mas ainda há forte tendência de oposição à legalização da poligamia, por razões estritamente morais/religiosas. Assim, contrariando o senso comum, pode-se dizer que o muçulmano é estritamente mais monogâmico que o(a) brasileiro(a). Ainda, pode-se afirmar que, embora o Brasil se declare laico, na prática não há uma demarcada separação entre Estado e religião. Já nos países declaradamente islâmicos, o Direito é uma das facetas da religião. Paradoxalmente, seria então o Brasil a estar encoberto pelo véu do islã? A metodologia utilizada é a exploratória, a partir de uma perspectiva comparada, tomando-se as cautelas necessárias para se respeitar as diferenças entre os dois sistemas.

Palavras-chave: poligamia; Direito islâmico; Brasil; moral; religião.

\section{INTRODUCTION}

In a discussion about the registration of 3 poly-union unions in Brazil, the National Justice Corregidor of the National Justice Council ("CNJ”), minister João Otávio Noronha, in his vote, said that "the very few cases in the country are not suitable for demonstrating changes in social thinking and

\footnotetext{
${ }^{1}$ Pontifícia Universidade Católica do Paraná. Paraná. Brasil.

${ }^{2}$ Faculty of Law of the University of Alexandria (Egypt). Egito.
} 
lead to recognition of the family entity. Brazilian society did not incorporate poly-union as a form of family formation".

Regardless of the legality or not of the registration, poliaffective (and polygamous) unions in Brazil exist and will continue to exist. It is a present reality and it is a mistake to think that polygamy is characteristic of the Islamic world. Even in Brazil, legal effects of these relationships have been recognized.

From this, the purpose of this article is to analyze the subject of polygamy in Brazilian and in Islamic legal system and to verify, from a critical perspective, whether polygamy is contrary to the legal system or to the morality. For this objective, some initial considerations must be made.

The first consideration is related to the expression "Islamic law", which may be used in a broad or in a strict sense. In a broad sense it refers to the whole set of rules, jurisprudence and doctrine of this legal system. In the strict sense it is used as a synonym for Sharia'a, which encompasses only the positive norms, considered primary sources of Islamic Law: the Quran (Qu'ran) and the Sunnah. In this study, the expression "Islamic law" will be used in its broad sense.

The second consideration is that Islamic law is not a legal system created by a state or a political power. It has a sacred origin and nature, where God-legislator established the rules and the human being only complies or creates norms compatible with them. It is, therefore, before the formation of any State and will survive eternally. Its precepts are addressed to every Muslim, regardless of where they are. This makes Islamic law a timeless and non-spatial system (NASSER, 2012, p. 729-730).

Thus, when talking about Islamic law, it is referring to the legal system and jurisprudential that derives from the religion Islam and that governs and regulates the human behavior and the social relations of the Muslims, wherever they are. A complex question arises about the relationship between the Shari'a and the domestic law of the countries, but which will not be the object of study in this article. The considerations made throughout the text will presuppose the application of this Law in relations, and that the possible conflicts between two legal systems of different natures have already been solved ${ }^{3}$.

The third consideration is that Islamic law, as a legal system, may be partially or totally incorporated in the countries. There are States that declare themselves Islamic in their constitutions, but which the low of the application of other norms in some cases, as is the case of Egypt ${ }^{4}$. Others adopt Islamic law fully, not allowing the application of other systems. Thus, the fact that the State opts for Islam as the official state religion does not imply that Islamic law will be the only legal system in

3 To deepen the theme, check out: BADR, 1978; NASSER, 2012. The author states that unless the State considers it to be Islamic law all its right or, on the contrary, denies any place to Islamic law, it will be necessary to consider the possible relations between two legal systems of various natures (free translation).

4 The Constitution of Egypt in articles 2 and 3 establishes that "islam is the religion of the state and Arabic its official language. Principles of Islamic Sharia are the principal source of legislation" and "the principles of the laws of Egyptian Christians and Jews are the main source of laws regulating their personal status, religious affairs, and selection of spiritual leaders". (EGYPT, 2014). About the Egyptian Constitution, Mohamed 'Arafa $(2014$, p. 891) says that "the Preamble to the Constitution also favors the secular and liberal elements without referring to any definition of Islamic Sharia, considering it sufficient to state that the "definition of Islamic Sharia must follow rulings issued by the Supreme Constitutional Court," and giving the high court exclusive authority to "interpret constitutional articles in its rulings" as explained". 
force. As well as the fact that states do not declare themselves Islamic does not means that Islamic law will not be applied.

The fourth consideration necessary to avoid confusion is that Islamic law can't be confused with the positive law of secular states of predominantly Muslim population. A country with a majority of the Muslim population can be secular and produces its own legal system (LIPOVETSKY E SILVA, 2009 , p. 49-50) ${ }^{5}$. This is the case of Turkey, which has $99 \%$ of the Muslim population but is reportedly secular ${ }^{6}$.

The fifth consideration to be made is the difficulty of conducting comparative studies between two very different legal systems. Faced with the vastness of the Islamic world, each country has different characteristics, history and political and socio-economic conditions. In view of this, one must seek, from a given legal institute, points of confluence and divergence (DIMOULIS, 2016, p. 85) ${ }^{7}$. In addition, this issue is not treated in the same way in Islamic countries, and oscillations can be verified (ABDAL-HAQQ, 2002, p. 35-41). Thus, the analysis will be performed in general, within what can be generalized.

The sixth and last consideration is that the subject of polygamy is treated differently in Brazil and in Islamic law, and goes beyond the law to the issue of morality/religion. When the legislator or the interpreter of the law uses religious convictions in a legal decision, he is mixing Law and moral. However, an understanding can be influenced by morality without a religious character. ${ }^{8}$

From this, the article will be developed in the following way: (a) it will approach the influences of the moral in the Brazilian Law and in the Islamic Law; (b) it will verify the contours of the notion of conjugality in Brazilian and in Islamic Law; (c) it will characterize the institute of polygamy in the two legal systems.

\section{THE INFLUENCES OF MORALITY IN LAW: AN ANALYSIS OF THE BRAZILIAN AND THE ISLAMIC LAW}

In Brazilian and in Islamic law, morality influences on Law occurs in a very different way. While in Brazil the interpreter may not - or should not - conduct a judgment in accordance with his or her

\footnotetext{
5 In the following countries, although with a predominantly Muslim population, there is a declared division between state and religion. They are: Albania, Azerbaijan, Bangladesh, Burkina Faso, Chad, Gambia, Guinea, Kazakhstan, Kosovo, Kyrgyzstan, Mali, Northern Cyprus, Nigeria, Senegal, Syria, Lebanon, Tajikistan, Turkmenistan, Turkey and Uzbekistan. (WORLD ATLAS).

6 Article 2 of the Turkish Constitution: "the Republic of Turkey is a democratic, secular and social State governed by the rule of law [...]". (TURKEY, 1982).

7 The comparative study of constitutional law should identify networks of influence and collaboration between legal systems (free translation). (DIMOULIS, 2016, p. 85). That is, if the institutes are identical or distinct, there is no way to perform comparative studies between them. It is necessary, therefore, to point out points of confluence and divergence, so that, eventually, some adaptation could be done in the local legal framework.

8 A loving relationship between siblings is considered an example of what for many people is morally unacceptable. It is thus verified that morality is wider than religion.
} 
moral and/or religious beliefs ${ }^{9}$, in Islamic Law, in some areas of Law, there is the use of Quran principles and injunctions (ABDAL-HAQQ, 2002, p. 33). ${ }^{10}$

Considering that the subject of overlaps between morality and law is extensive, this point will be systematized as follows: (i) the separation of law and morality from a juspositivist view; (ii) moral influences on Brazilian law, focusing on families laws'11 and the relativization of the secular state in certain judicial decisions; (iii) the influence of morality (religion) on Islamic law.

\subsection{The separation between law and morality in juspositivism}

In the juspositivist view, ${ }^{12}$ morality would have its object to distinguish good from evil, to guide people's behavior and to evaluate individual conduct. There are three different forms of morality: dominant morality, personal morality and critical morality. The dominant morality would be imposed by (or in) society. Personal morality would be the values that each subject accepts and that guide their conduct. Critical morality, on the other hand, is the result of historical research in which philosophical arguments are presented to present the set of best values and principles about human conduct (DIMOULIS, 2006, p. 167).

Lawyers who reject the link between morality and law accept the existence of personal morality; however, they argue that it is not relevant to the law. There are also juspositivists who accept the existence of objective morality, but also deny its relevance to the law. Dimitri Dimoulis sets the example of a Catholic with unshakable faith in the moral teachings of his religion, who can objectively study the legal system without changing his stance against morality. However, probably in the legal gaps that require interpretation of the judgment, this fervent Catholic will conduct his decision on the basis of moral teachings (DIMOULIS, 2006, p. 168-169).

Dimoulis (2006, p. 168-169) presents four interpretations of this thesis about the separation of law and morals which are done in the wrong way. The first is that positivism denies any moral influence on law. The juspositivist affirms that the interpreter of the law cannot modify the decision of the legislator when there is divergence between law and justice. In other words, only the creator of the norm can take into account the moral; the applicator must decide to take into account only what was created by the legislator. For example, the legislator could create a rule that provides for a decision

\footnotetext{
9 Religion should not have influences in the legal system, in view of what advocates the Constitution of 1988, which is the state secularity: Article 19 - it is forbidden to the Union, the States, the Federal district and the municipalities: I- establish religious services or churches, subside them, embarrass them the functioning or maintain with them or their representatives relations of dependence or alliance, except in the form of the law, the collaboration of public interest (free translation). However, as will be seen later, the Brazilian secular state, in several opportunities, is put in check (BRASIL, 1988).

10 “There are two primary sources of Islamic law - the Qur'an (Koran) and the Sunnah (traditions of Muhammad ibn Abdullah, the last prophet of Islam)". (ABDAL-HAQQ, 2002, p. 33).

11 In this article, the expression "families laws" will be used instead of "family law", in view of the need to incorporate and protect, without discrimination, all possible families models.

12 On the other hand, for naturalists, the content of the positive law must take place through a moral order, so that the right is subordinated to the moral system, only if there is a legal obligation due to a moral obligation (NOGUEIRA, 2010, p. 134-135).
} 
according to moral values. Therefore, the applicator would be deciding basis of values by virtue of the norm.

The author (2006, p. 177) still points to the neutrality that the state must have in relation to moral values. Thus, the legislator cannot impose all its principles and moral values, as this violates the principle of individual freedom in choosing the precepts and values that the subject believes without submitting to an official and tax morality.

However, Pierre Legrand (2012, p. 30-31) alerts to the impossibility of the subject to dissociate himself from his pre-concepts and preconceptions ${ }^{13}$ even this is a strict juspositivist. This is because, if the interpreter or the comparator, he will use meaning from his reading of the world. Therefore, as will be verified, the difficulty faced by the separation of law and morality by the interpreter or legislator and also by comparative studies of a legal institute, since it will be the interpretation of the native and foreign law carried out by the authors (from its historicity).

\subsection{The influence of morality on Brazilian families' laws}

Some of the influences exercised by morality in Brazilian legal system would have as a cut off the families' laws, because this area is related to the subject of polygamy - this is because it would not be possible to work all the influences of morality on the law in an article.

Firstly, there is no way to deal with morality influences in Brazilian legal system without going into the aspect of state secularism (since many controversial decisions will touch this aspect of the Brazilian State). The Federal Constitution of 1988 prohibits federal entities from establishing religious services or churches and maintaining relations of dependency or alliance. ${ }^{14}$ The Constitution of 1891 already provided for the secularity of the Brazilian State.

Thus, religion in Brazil should not influence the legal order, in order to adapt laws and codes according to its principles, but should be based only on social ethics.

However, in practice this is not what is observed. What is verified is a strong morality/religious influence on Brazilian legal system. ${ }^{15}$ Beginning with the preamble of the 1988 Constitution, which

\footnotetext{
13 Regarding the preconceptions and the impossibility of completely unlinking them, it relates to Gadamer's conception of hermeneutics. In addition, language is fundamental in understanding because all comprehension is interpretation, and interpretation develops through language, thus having an essential relationship between language and comprehension (GADAMER, 1997). Gadamer questions how it would be possible to understand, developing that it is only explicable from our history and tradition, linked to customs and traditions. In this way, our consciousness is determined by history. The historicity, for the author, is the positive condition for the knowledge of the truth, because we belong to history (OLIVEIRA, 1996, p. 225-236).

14 Article 19, paragraph I: the Union, the States, the Federal district and the municipalities are prohibited: to establish religious services or churches, to subside them, to embarrass them, or to maintain with them or their representatives relations of dependence or alliance, in the form of law, collaboration of public interest (free translation) (BRASIL, 1998).

15 Kreuz (2018) call this phenomenon of secularism "à brasileira". For the authors, the Brazilian State goes through confusion and interference of religious elements in the public sphere. Formally have a separation between State and religion, with the possibility of collaboration for the purpose of public interest; in practice, religious elements permeate public spaces, symbolic or physical, as well as the political and legal sphere, reaching even the public education (free translation). About secularism and education education check out the
} 
refers to the "protection of God" (as well as the institution of the Democratic State, the exercise of social and individual rights, among other issues). ${ }^{16}$ The National Constituent Assembly (KREUZ, 2018) debated the reference to God ${ }^{17}$ but majority retained the reference in the preambular text.

Brazilian courts and municipal, state or federal legislative buildings, as well as several other public buildings (universities, schools, hospitals, and barracks) often have crucifixes on their walls. ${ }^{18}$ This issue may lead to a view of partiality of the Judiciary, especially when issues in which the favored religion has a standing position are involved, as has invariably occurred in Brazil in cases involving sexual and reproductive rights. On the other hand, the presence of this symbology can influence the judges in making their judgments, although they have to rationally filter their religious preconceptions (SARMENTO, 2007).

Church also played an important role in the process of transition from the military regime, which lasted for 21 years, from 1964 to 1985, to the construction of a Democratic State, outlined by the Constituent Assembly. The National Conference of Bishops of Brazil ("CNBB") was committed to attacking the government head-on and had a strong involvement in the constituent process. The "CNBB" ensured that it should be given a decisive role for society, based on instruments for the exercise of democracy (BARBOSA, 2012).

Under the families laws, there is also a strong influence of morality/religion. Some examples may be mentioned.

(i) The Federal Supreme Court ("STF") decision on the possibility of abortion of anencephalic fetuses in the judgment of the claim of non-compliance with a fundamental precept ("ADPF") No. 54, had 8 favorable votes and 2 contrary votes (from the ministers Ricardo Lewandowski and Cezar Peluso). Minister Dias Toffoli did not take part in the vote because he declared himself unable to attend.

It is observed that the two opposing votes reveal aspects related to morality/religion. The vote by Minister Ricardo Lewandowski raises questions of moral conviction, for example, when he says that abortion allowance for anencephalic fetuses would open the door to the interruption of the gestation of

decision of the Federal Supreme Court about the possibility of denominational religious teaching in public schools, given in the Direct Action of Unconstitutionality ("ADI") No. 4439.

16 Preamble of the Federal Constitution of 1988: We, representatives of the Brazilian people, gathered in the National Constituent Assembly to establish a democratic State, in order to ensure the exercise of social and individual rights, freedom, security, prosperity, the development, equality and justice as supreme values of a fraternal society, pluralist and unprejudiced, founded on social harmony and compromised, in the internal and international order, with the peaceful settlement of disputes, promulgate, under the protection of God, the following Constitution of the Federative Republic of Brazil (free translation) (BRASIL, 1998).

17 There was only one vote, Haroldo Lima (of the Communist Party of Brazil), for the deletion of the words "under the protection of God". It was declared by some members of the constituent Assembly, including the refusal of God protection would go against the faith of Brazilians, starting from a false premise that there are only Brazilians Christians (KREUZ, 2018).

18 Daniel Sarmento (2007) rightly says that the presence of this religious symbol at the session rooms of the courts - usually in a position of absolute prominence, behind and above the chair of the president, conveys a not neutral message, associating the jurisidicional provision with the majority religion, which is frankly inconsistent with the principle of secularism of the State, which demand the State neutrality on religious issues (free translation). 
innumerable other embryos. ${ }^{19}$ Minister Cezar Peluso affirms that the anencephalic dies because he is alive, thus developing his vote from the perspective that, even if the fetus is doomed to death, there is intrauterine life. ${ }^{20}$

Also, it should be noted that, in order to have the participation of representative entities, there were public hearings, which included scientific and social entities, as well as religious entities. In this way, it is verified that the Brazilian State, although secular, included religious entities in a subject that should not have a religious connection. As Maria José Rosado Nunes said, "[...] many of the arguments against women's freedom of choice in the reproductive field, although presented as coming from a single scientific stream, would in fact be the expression of a doctrine and a specific religious morality". ${ }^{21}$

(ii) The conception of a family still predominant is the one built around the patriarch, formed monogamous and heteroaffectively. In the Christian Bible, the apostle Paul recommends that: "women, subject yourselves to your husbands, as to the Lord; For the husband is the head of the wife, even as Christ is the head of the church, being himself the savior of the body. Therefore, just as the church is subject to Christ, so also let women be subject to their husbands in everything" (HOLY BIBLE).

(iii) The submission of the will of women is also expressed when criminalizing abortion. This issue has been the subject of intense debate, including through the claim of non-compliance with a fundamental precept ("ADPF") No. 442 asks that abortion done in the first 12 weeks of gestation should not be considered a crime. It was the largest public audience (in number of exhibitors) that happened in the "STF" and the case with the largest number of amicus curiae offered in Brazilian constitutional history (CARTA CAPITAL).

Maria José Nunes, representing the group "Catholics for the Right to Decide" in the public hearing held before the "STF" began the trial of "ADPF" 442, emphasized that "a secular state isn't against religions, but does not allow it to be imposed on all society, increasingly diverse in its religious adherents, the norms and agenda of a single religion" (DIÁRIO CENTRO DO MUNDO).

19 It is easy to conclude that a judicial decision exempting the abortion of fetuses with anencephaly, at the end of the current penal legislation, as well as debatable from the ethical, legal and scientific standpoint, in view of the different aspects that this Pathology can present in real life, would open the doors for the interruption of the gestation of countless other embryos that suffer or will suffer other diseases, genetic or acquired, which, in some way, lead to the shortening of their life intra or extra uterine (free translation). (BRASIL. Federal Supreme Court. Claim of non-compliance with a fundamental precept No. 54).

20 In an extract of his vote, Minister Cezar Peluso declares that brought to the last consequences, the principles sustained by the author - and this is always latent risk - could a satanic religion or a demonic cult advocate, as lawful and moral, the realization expiatory of human sacrifices, using the same argumentative bases. In more direct terms, religious freedom, allied to other legal values, such as, for example, individual autonomy, impertinent but deceptibly invoked, would alienate the criminal typicality and the dispurpose of these abominable conducts, which would cease to disgusts the civilized spirit and would no longer represent cruel homicides, because, in a kind of severe intellectual myopia, they would be seen under the illusion of the shadow of religious freedom and other constitutional values adulterated as justification (free translation). (BRASIL. Federal Supreme Court. Claim of non-compliance with a fundamental precept No. 5

21 The author also complements that the circumstance that the Brazilian state is constitutionally characterized as secular and the fact that Brazilian society's regulatory laws have to reflect this untying (free translation) (BRASIL. Federal Supreme Court. Claim of non-compliance with a fundamental precept No. 54). 
(iv) Another influence is found in the social function of the family, which is predominantly linked to procreation. In the book of Genesis, the precept taught is "grow and multiply". For this, the reproduction of the family is connected to the heterosexual relationship, which is the one that guarantees the biological reproduction, the future heirs, by means of which the material and immaterial patrimony, received from the father figure, will be perpetuated.

\subsection{The influences of morality on Islamic Family Law}

In Islamic law there isn't separation between religion and law, all laws being based on religion and based on the sacred scriptures or the opinions of religious leaders. Thus, Islamic law is an unfolding of the Islam religion, even sharing the same sources.

The primary sources are the Qur'an (Qu'ran), which is the main source of Islamic law, and the Sunnah, which are the words (called Hadith) and the acts that the Prophet Muhammad practiced or refrained from practice (their standards of conduct). These two sources constitute the Shari'a. The secondary source is jurisprudence (Fiqh), which is responsible for the application of Shari'a (ABDAL$H A Q Q, 2002)$.

The Shari'a is the fruit of divine revelation (Allah), and over time has been shaped from theories and interpretations. This has resulted in several schools of thought, which can range from Islamic countries to even within the same country (BASSIOUNI; BADR, 2002).

Giving some examples of these influences of morality/religion into the scope of Islamic family law, it is observed that, because of these primary sources in legislation, there are situations in which there are no equal rights between men and women. ${ }^{22}$ In divorce, for example, a man may request it at any time and without any cause/justification, whereas a woman can only apply for divorce if the husband is recalcitrant or under limited circumstances (LEICHTER, 2009).

As for the custody of the children, the father usually receives legal custody or is appointed as his guardian (wilāyah). If the father cannot be the guardian of the child, the Court will appoint an Islamic judge to serve in the function. The guardian has power over the property interests of the child and may enter into contracts on behalf of the child.

Already the principle of inheritance distribution in Islam is that the portion for a male beneficiary is equivalent to two parts of the beneficiary of the female sex. ${ }^{23}$ Still, the first part of the estate of the deceased, which is automatically divided among the heirs, must obey the supposed

22 Quran 4:34: "Men are the protectors and maintainers of women because Allah has made one of them excel over the other and because they spend out of their possessions (to support them). Thus righteous women are obedient and guard the rights of men in their absence under Allah's protection. As for women of whom you fear rebellion, admonish them, and remain apart from them in beds, and beat them. Then if they obey you, do not seek ways to harm them. Allah is Exalted, Great" (THENOBLE QUR'AN).

23 Quran 4:11: "Allah instructs you concerning your children: for the male, what is equal to the share of two females. Nevertheless, if there are [only] daughters, two or more, for them is two thirds of one's estate. And if there is only one, for her is half. And for one's parents, to each one of them is a sixth of his estate if he left children. However, if he had no children and the parents [alone] inherit from him, then for his mother is one third. And if he had male siblings [or Female siblings], for his mother is a sixth, after any bequest he [may have] made or debt. Your parents or your children - you know not which of them are nearest to you in benefit. [These shares are] an obligation [imposed] by Allah. Indeed, Allah is ever Knowing and Wise" (THE NOBLE QUR'AN). 
superiority of man. Thus, children receive more than daughters, parents receive more than mothers and brothers receive more than sisters.

As for premarital sexual encounter, it is forbidden. Before marrying, in order not to harm the honor of the family, a man should fast not to lose control of his desires. ${ }^{24}$

There is also a prohibition of legal adoption in Islamic law. ${ }^{25}$ This situation stems from the fact that it is wiser for Allah to keep the child with the surname of the biological family. Orphans, however, have the right to be treated with dignity and respect, since they are brothers of religion.

\section{THE NOTION OF CONJUGALITY IN BRAZILIAN LAW AND IN ISLAMIC LAW}

In view of the plurality of relationships that have recently developed, a broad term - conjugal union - is chosen that is capable of encompassing marriage, stable union, and non - formalized unions.

Preliminarily, it is necessary to delimit the understanding of the term conjugality, so that, if these terminological precisions are fulfilled, polygamy can be characterized. In this article, this term will be used to designate the affective and stable union of people who have the intention of forming a family (animus familiae). Thus, temporary unions for other purposes will not be considered marital.

Moreover, the ostensibility is not considered an indispensable criterion for the constitution of this relationship, since many relationships are kept secret for many reasons, but they are no longer considered as marital relations.

\subsection{Conjugality in Brazil}

The formal conjugal union in Brazil can be as much by the marriage as by the stable union. ${ }^{26}$ Both are explicitly recognized in the Federal Constitution as family entities (LÔBO, 2004).

There is no legal definition of marriage, despite the fact that it is treated in 110 articles of the Brazilian Civil Code. In this code, article 1.511, the requisites of celebration are established, the rights and duties of the spouses are listed, the regimes of property are regulated and the end of the marriage is regulated. However, the law defines its purpose, to establish full communion of life, on the basis of

24 Quran 2:235: "There is no blame upon you for that to which you [indirectly] allude concerning a proposal to women or for what you conceal within yourselves. Allah knows that you will have them in mind. But do not promise them secretly except for saying a proper saying. And do not determine to undertake a marriage contract until the decreed period reaches its end. And know that Allah knows what is within yourselves, so beware of Him. And know that Allah is Forgiving and Forbearing" (THE NOBLE QUR'AN).

25 Quran 33: 4-5: "Allah has not made for a man two hearts in his interior. And He has not made your wives whom you declare unlawful your mothers. And he has not made your adopted sons your [true] sons. That is [merely] your saying by your mouths, but Allah says the truth, and He guides to the [right] way. Call them by [the names of] their fathers; it is more just in the sight of Allah. But if you do not know their fathers - then they are [still] your brothers in religion and those entrusted to you. And there is no blame upon you for that in which you have erred but [only for] what your hearts intended. And ever is Allah Forgiving and Merciful" (THE NOBLE QUR'AN).

26 Article 1,723, caput, of the Brazilian Civil Code of 2002, provides that it is recognized as a family entity the stable union between man and woman, configured in public coexistence, continuous and lasting and established with the goal of family formation (free translation) (BRASIL, 2002). 
equality of rights if the duties of the spouses (BRASIL, 2002), and their effects, by providing that men and women mutually assume the status of consorts, companions, and caregivers (DIAS, 2015, p. 147).

Marriage can be civil or religious. ${ }^{27}$ The rules of the former are defined by the state, while those of the latter are determined by each religion. Religious marriage, however, has civil effects as long as the legal requirements are met. ${ }^{28}$

It is important to emphasize that marriage is consumed at the time of the conclusion of the contract $^{29}$ (moment of "yes"), and not later in the marriage bed. It does not depend on the couple's sexuality.

As for homoaffective marriage, there is no consensus in doctrine. However, in 2013 the National Council of Justice ("CNJ") issued a resolution ordering that notaries should marry same-sex couples by forbidding competent authorities to refuse to authorize or enter into civil marriage, or even to convert a stable marriage into marriage. ${ }^{30}$

Already the concept of stable union is in the Civil Code of 2002, in the caput of article 1.723, which recognizes as a family entity the stable union between man and woman, configured in public coexistence, continuous and lasting and established for the purpose of family formation. It can be observed that there is not minimum time requirement for its characterization, nor cohabitation.

Supreme Federal Court, even in deciding for the unconstitutionality of the distinction between succession regimes between spouses (marriage) and companions (stable union), ${ }^{31}$ based on the principle of equality intended to close with all and any differentiation. Both in the scope of the Law of Succession and in the families' laws and in all the distinctions established on legislation.

It is worth remembering that in spite of the Federal Constitution mentioning the diversity of the sexes in the stable union, ${ }^{32}$ it is legally possible for stable homoaffective union. The Federal Supreme Court rendered a historic judgment in 2011 recognizing this possibility. ${ }^{33}$

There is also a detachment of formal relations, for various reasons, so that there have been innumerable marital unions without formalization through marriage or stable union. This has

27 Until the nineteenth century, marriage was seen in western societies merely as a trade agreement between two families, where the "grooms" had no voting power. The movement of romanticism came to alter this image and then there was the idea of marrying for love.

28 Article 1,515 of the Brazilian Civil Code of 2002: religious marriage, which meets the requirements of the law for the validity of civil marriage, equidates itself to this, provided that registered in the own register, producing effects from the date of its celebration (free translation).

29 The doctrine diverges as to the legal nature of marriage.

30 Article 1 of resolution No. 175/2013: the competent authorities are forbidden to refuse the habilitation, the celebration of a civil marriage or the conversion of stable marriage into wedding between persons of same sex (BRASIL. National Council of Justice. Resolution No. 175).

31 Thesis of general repercussion of the "STF": It is unconstitutional the distinction of succession regimes between spouses and companions foreseen in article 1,790 of the $\mathrm{CC} / 2002$, and should be applied, both in the hypotheses of marriage and those of stable union, the scheme of article 1,829 CC/2002 (free translation). (BRASIL. Federal Supreme Court. Extraordinary resources No. 878.694 e 646.721).

32 Article 226, § 3: For the purpose of the protection of the State, the stable union between man and woman as a family entity is recognized, and the law should facilitate their conversion into marriage (free translation) (BRASIL. Constitution of the Federative Republic of Brazil).

33 This recognition was made from the judgment of Direct Action of Unconstitutionality No. 4177 and ADPF No. 132. 
contributed to the expansion of the notion of family as a "bond of affection that generates responsibilities" (DIAS, 2017). Maria Berenice Dias defends that "it is not the legal imposition of norms of conduct that consolidates the conjugal structure. It is simply the sincerity of feelings and the awareness of the roles played by its members that guarantee the survival of the relationship, as the thirst for personal development and fulfillment" (DIAS, 2000).

Thus, the intention to constitute a family is sufficient, being indifferent if they formally register in the civil registry or in the registry, or if they simply have the purpose to live together. The rights and duties are the same. It should be noted that the conjugal union without formalization has grown greatly among Brazilians.

\subsection{Marital Union in Islam}

In Islamic law, marriage is the only form of conjugal union recognized and protected by law. A contractual relationship stipulates reciprocal rights and responsibilities for each spouse whose main purpose is to regulate sexuality within marriage (ELTAHAWY, 2015) and create an atmosphere for the continuity and expansion of the family. It is so much that children not born in marriage have no legitimacy and do not share the inheritance of their parents.

In general, the wife (zawja) has the right to be kept by her husband (zawj) and owes her obedience, and the latter can control the woman's leaving home, as well as visiting relatives. As for the possibility of working, the woman can do so, provided she receives authorization from her husband.

We can list some characteristics of this contract, called Nikah: there is no need for a religious authority (imam - person who leads mosque prayers) to conduct the ceremony; must be signed before two witnesses (they must be adults).

The marriage proposal can be offered to the man by the woman or her guardian (usually father or brother) or vice versa. In the case of mutual acceptance, there is usually the payment of a dowry (called "mahr" or "saddaq") (LEICHTER, 2009). ${ }^{34}$ After the conclusion of the contract (which can be signed between the man and the woman or between the man and the woman's guardian), the latter has two main effects: women provide sexual favors and in return they gain the right to livelihood. It is emphasized that sexual intercourse, as consummation of marriage, is a condition of validity.

It is emphasized that Islamic communities allow inbreeding, which is marriage between close relatives. ${ }^{35}$ Thus, it is common for first-degree cousins to marry. Another interesting question is that women cannot marry ${ }^{36}$ men who are not Muslims. Men can marry non-muslim women.

\footnotetext{
34 Generally, (although this varies according to custom), a small portion of the Mahr is delivered in the signature of the agreement, and another part, much larger, is paid when there is divorce or death of the husband. The parties may also stipulate in the contract that this other party is delivered at any time, under the wife's demand (LEICHTER, 2009).

35 The Quran prohibits marriage with mothers, daughters, sisters, aunts, nieces, "milk mothers", "milk sisters", stepchildren, daughters in law and widowed mothers. (Quran 4:23).

36 There are studies that highlight the negative effects of these consanguineous marriages, as we can see: TADMOURI, 2009.
} 
As stated, marriage generates for each of the parties rights and duties deriving from the Shari'a. Some of these, however, vary among Islamic countries, and may be increased or reduced. For example, in many Islamic countries, a wife may enter into the marriage contract the reasons why she may have the right to divorce ${ }^{37}$ (even without the consent of the husband). ${ }^{38}$ On the other hand, the marriage contract can't alter the husband's unrestricted right to divorce his wife without just cause, since that right is considered unalterably granted to the husband by the Shari'a (LEICHTER, 2009).

When the husband wishes to divorce, he must pronounce the word "talaq" (which means: I repudiate you) three times. However, it cannot be pronounced when the woman is in her menstrual period. After pronouncing the first time, the next two should occur during each of the periods after the cessation of the wife's menstrual cycle. In some cases, it is permitted to pronounce "talaq" three consecutive times. After that, the woman stays in an idda, or waiting period, for three months, during which she is forbidden to remarry. In this time span, man must continue to provide his sustenance. After that time, your obligations cease (LEICHTER, 2009). ${ }^{39}$

Lastly, there is a mode of marriage between shiites known as Mut'a, which is a temporary marriage contract, which can last from a few minutes to ninety-nine years. During the Mut'a, sexual union and the possible children generated are legitimate. The Mahr's payment must be definitive and the husband's control over the wife is reduced. On the other hand, the woman does not have the right to the sustenance. The end of the Mut'a is with the termination of the contract. It should be noted that as long as the man simultaneously performs as many weddings as Mut'a he wants, the woman can only do it one at a time. At the end of a Mut'a, you can only hire another after the 'idda' (LEICHTER, 2009).

\section{POLYGAMY IN ISLAMIC LAW AND IN BRAZILIAN LAW}

37 The Shari'a predicts six ways to dissolve the Nikah: 1. Divorce by repudiation (Talaq) - Talaq Ahsan, Talaq Hasan, Talaq Bid'ee; 2. Constructive Divorce - Ila, Zihar; 3. Divorce Delegated (Talaq Tawfiq); 4) Compensacional divorce (Khula); 5) Separation/annulment - Fasku, Tafriq; 6) Apostasy (Riddah).

38 Here it is important to point out that the woman may initiate the divorce, but for either should either give up partial or entirely of her right to the "Mahr" provided in her marriage contract, or offer some other compensation to the husband for this to allow the divorce. This consented divorce is called "Khul or Mubarat". In some circumstances the courts may grant a divorce to a woman for specific reasons, such as when the husband is guilty of acts prohibited by Shari'a, even if the husband does not consent to divorce. It is called "Tatliq or Tafriq". In this case, the wife still has the right to "Mahr". Still, in most Islamic countries, the marriage contract itself can stipulate specific reasons why a woman has the right to request and obtain an unconditional divorce without abdicating her "Mahr". Some of the reasons may be when the husband marries a second wife or when he prohibits her from working. However, these reasons should also be proved in the Shiite court, and the right to divorce is subject to the decision of the judges (LEICHTER, 2009).

39 Even, Shari'a does not foresee any support from her husband after divorce, such as pensions, for example. For this reason, in the marriage contract must be established the "Mahr" that the wife receives with the end of the pact. It is important to emphasize that Nikah also presupposes the application of Shari'a to prevent the wife from claiming any property acquired during the marriage with the husband's efforts or property on his behalf. The woman, in addition to the "Mahr" is only entitled to the goods that are in her name and her own gains during the marriage that still remain after the divorce (LEICHTER, 2009). 
Polygamy, according to the Houaiss dictionary, is the conjugal union of one person with several others. It contains two species: polygyny, when a man marries more than one woman or polyandry, when a woman marries more than one man.

Initially it is important to distinguish the expressions: polyphasic or polyamine unions, polygamy, and parallel or simultaneous unions. The distinction between the first two lies in affection. In polygamy, a conjugal union does not necessarily have love as its basis. The purpose may be different, such as patrimonial, for example. On the other hand, a poliaffective union is a conjugal union centered on the principle of affectivity. In these two situations there is usually cohabitation. ${ }^{40}$ Parallel unions are those where marital bonds do not happen under the same roof, having one element in common (usually man).

It is worth mentioning that one type of relationship does not exclude the other. It is possible, for example, that a polyphasic relationship is also polygynous (for example in the case of two women and a man who live together and have animus familiae). Similarly, a parallel union may also be polygynous (for example in the case of a married man owning two families in separate households, with animus familiae in both).

Another consideration is that the coexistence of two or more affective relationships (polyamorous) presupposes the consent and acceptance of those involved. In polygamy, there are not always these elements, since affection is not necessary for its characterization, occurring in many cases in secret or without the consent of the non-common part.

Still, it is necessary to deal with the two-dimensionality of polygamy. Exogenous polygamy is one that arises out of conjugalities external to an original family community. However, the endogenous is composed of multiple conjugalities inserted in the same family group (PIANOVSKI, 2006).

\subsection{Polygamy in Brazilian Law}

The Brazilian legal reality in the area of families' laws is complex. As we have seen, marriage is not the only form of conjugal union, but only one species among others.

One possible consequence of this is that, since homoaffective union is allowed, one can have other types of conjugal arrangements, other than polygyny or polyandry, such as a man who marries several men and a woman who marries several women, or a man who marries a man and a woman or a woman who marries a man and a woman.

Thus, when one speaks of polygamy in Brazil, one can refer both to the multiplicity of marriages, to stable unions, or to unformalized unions, but to the constitution of a family.

In the West, the predominant historical conjugal model is monogamous, that is, where the individual has only one partner or partner at a time (DIAS, 2015, p. 42). ${ }^{41}$ In Brazil, the structure of

\footnotetext{
40 The expression was generally used because there is a "STF" precedent that the life in common under the same roof, is not indispensable to the characterization of concubinate (BRASIL. Federal Supreme Court. Precedent no 382).

41 Maria Berenice Dias (2015) says that monogamy was not instituted in favor of love. This is a mere convention arising from the triumph of private property over the primitive condominium state. It serves much
} 
the family is based on this model, elected by the State, and even bigamy crime punishable by imprisonment. ${ }^{42}$ It is important to emphasize that stable union has no relevance to this offense, but only valid and prior marriage. 43

The Brazilian Civil Code does not admit bigamy (and consequently polygamy), and when it comes to unions parallel to marriage, it is called concubinage,${ }^{44}$ dispensing with differential treatment of such relationships and withdrawing from them rights conferred on unions in which there is no impediment to marriage between those involved. ${ }^{45}$

Because of this legal prohibition, Brazilian jurisprudence tends not to recognize the legal effects, in the context of families laws, of the concomitant relationship(s) to the monogamous union (DIAS, S.I.).

However, the 1988 Federal Constitution gives special protection to the family. ${ }^{46}$ It is understood, therefore, that the State must interfere in this scope only in the sense of protection, not of exclusion. It must therefore restrict itself to declaring the existence of a family, independent of its form and conferring social protection on it (ALBUQUERQUE NETO, 2002, p. 150).

Based on this understanding, part of the Brazilian jurisprudence and doctrine has recognized polygamous unions to give those effects regarding social security and inheritance rights, among others.

In social security law, most of the doctrine understands the possibility of apportionment of a pension by death when there is an extramarital union. Those who understand this use the principle of protection of dependents, especially their centrality, and the principle of solidarity, emphasizing the predominantly alimentary nature of the death benefit (CORREIRA; CORREIA, 2012, p. 341).

The first-degree judicial decisions have been divided, so that sometimes the adoption of the current social security with its protective focus is chosen, determining the apportionment between wife and partner, or prevails the more traditional doctrine, eminently civilist, which denies the benefit.

more to patrimonial, succession and economic issues. Although uniconjugality has legal value, it is nothing more than a system of moral rules (free translation).

42 Article 235 of the Brazilian Penal code: Contract Someone, being married, new marriage: Penalty imprisonment, from two to six years. $\S 1-$ He who, not being married, contracts marriage with a married person, knowing this circumstance, is punished with imprisonment or detention, one to three years. $\S 2-$ annulled for any reason the first marriage, or the other for reasons other than Bigamia, is deemed to be nonexistent the crime. Polygamy, that is, the contraction of three or more marriages by the same person, also configures the offence. In this case, however, there will be a single crime of Bigamia, but several, in a crime contest (BRASIL. Decree-Law No. 2,848, of December 7, 1940. Penal code).

43 According to the Brazilian Civil code, cannot marry (article 1,521): I- The ascendants with the descendants, whether natural or Civil kinship; II- the related ones in a straight line; III- the adoper with whom he was the spouse of the adopted and the adopted with whom the adoptee was; IV-the siblings, unilateral or bilateral, and other collateral, up to the third degree inclusive; $\mathrm{V}$ - the adopted with the adopant's child; VI- married people; VII- the surviving spouse with the convict for murder or attempted murder against his consort (free translation) (BRASIL. Law No. 10.406, of January 10, 2002).

44 Article 1.727 of the Civil code: the non-eventual relations between man and woman, prevented from marrying, constitute concubinage (free translation) (BRASIL. Law No. 10.406).

${ }^{45}$ Article 1.801 of the Civil code: Cannot be named heirs nor legatarians: III-the concubine of the married tester, unless this, without his fault, has been separated from the spouse for more than five years (free translation) (BRASIL. Law No. 10.406).

46 Article 226, caput, of the Brazilian Federal Constitution: the family, the basis of society, has special protection of the State (free translation) (BRASIL. Constitution of the Federative Republic of Brazil). 
The decision of the Regional Court of Uniformization of the Federal Regional Court of the fourth Region, in an incident of uniformity, against a decision that dismissed the request for the grant of a death pension because the author maintained an extramarital relationship with the insured. The decision was that marriage parallel to marriage is not impeding the deferral of the benefit. ${ }^{47}$

The Federal Supreme Court has understood that there is no right to apportionment of death pension in the case of a long-standing extramarital relationship, overlapping the right of the spouse to receive the full benefit. However, this understanding can be modified by the judgment of two appeals with general repercussions: Extraordinary Appeal No. 883.168 (which discusses the possibility or not of recognition of a death pension for the person who maintained, for a long period and with family appearance, marriage to another married woman), ${ }^{48}$ and, also, Extraordinary Appeal No. 1045273 (in case the possibility or not of legal recognition of stable union and concomitant homoaffective relation, with the consequent apportionment of pension by death). 49

In the case of succession, the Supreme Federal Court's precedent No. 35 provides that "in case of an accident at work or transportation, the concubine has the right to be compensated for the death of the wife, if there was no impediment between them for marriage" (BRASIL. Federal Supreme Court. Precedent No. 35).

In the scope of the families' laws, also there is recognition of these unions. The Supreme Federal Court's precedent No. 380 provides that "proven existence of a partnership between the concubines, it is possible to dissolve it judicially, sharing the equity acquired by the common effort".

Finally, it is important to note that there have already been records of a stable union in Brazil, among them are the first, in 2012, between one man and two women and another in 2015, among three women (DAL PIVA, 2015). The National Justice Council (“CNJ"), however, when it was provoked by the Association of Family Law and Succession ("ADFAS") in June 2018, determined that the Inspectors Generals Offices prohibit the registries of their respective states from drafting public deeds for registration air couplings.

\subsection{Polygamy in Islamic law}

47 Decision: “INCIDENTE DE UNIFORMIZAÇÃO REGIONAL. PENSÃO POR MORTE. CONCUBINATO. UNIÃO ESTÁVEL. RATEIO DO BENEFÍCIO ADMITIDO. DIVERGÊNCIA DEMONSTRADA. 1. O acórdão recorrido contraria orientação jurisprudencial desta TRU de que "a existência de impedimentos ao casamento não obsta o reconhecimento de entidade familiar nas hipóteses de concubinato adulterino, quando da vigência de matrimônio válido sem separação, não retirando da concubina a proteção previdenciária, quanto às situações em que reste evidenciada a boa-fé, entendida essa não somente como o desconhecimento de supostos impedimentos ao casamento, mas também nas hipóteses em que a afetividade, estabilidade e ostensibilidade da relação revelem expectativa no sentido de que aquele relacionamento poderá evoluir para o casamento, dependendo do contexto probatório dos autos". 2. Incidente provido" (BRASIL. Regional Court of Uniformization of the Federal Regional Court of the 4th Region, Incident of uniformity No. 500106310.2012.404.7112/RS).

48 Theme 526: Possibility of long-lasting concubinage generating social welfare effects.

49 Theme 529: Possibility of legal recognition of a stable union and of concomitant homoaffective relationship, with the consequent assessment of pension by death. 
Polygamy in Islam is allowed and regulated by the Shari'a. The Qur'an states that “... you may marry two, three or four of the ones you please among the women. But if you fear that you can't be fair to them, then marry one".

From this passage, it is noticed that: (i) the permission of multiconjugality is only for the men (polygyny); (ii) four is the maximum number of wives allowed; (iii) equal treatment is required for all of them, both in relation to maintenance and expenses, as well as time spent and other obligations (ISLAM RELIGION, 2010).

It is important to note that permitted polygamy is the endogenous polygamy, so that the husband and the wife are as a single-family group. Exogenous polygamy, which would be the extramarital relationship of a married man or a married woman (adultery) is not allowed.

Yet, marriage and polygamy in Islam are a matter of mutual consent, not an imposition or imposition. In addition, there is the possibility of stipulating in the prenuptial agreement the prohibition of multiconjugality. In this contract, called Nikah, in some cases it is allowed to establish some other rights (LEICHTER, 2009).

For Islamic law, polygamy significantly reduces the likelihood of adultery and divorce, preferring it to treason. In addition, it allows every woman to be under the protection and guardianship of a spouse, thus being able to experience motherhood.In practice, what we do is that men do not feel secure in taking on the financial/psychological obligations of more than one wife. Research already conducted indicates that no more than $2 \%$ of married men practice polygamy (ISLAM RELIGION, 2010).

\section{CONCLUSION}

From the analysis of the types of marital unions and the possibilities of polygamy in Brazilian and in Islamic legal systems, and from the comparative study of these legal systems, it is possible to establish some similarities and differences between the two systems:

1. Islamic law is a facet of the Islam religion, the Koran being the main source of law. Thus, a strong influence of religion on the families' laws is observed, especially in the regulation of marriage. On the other hand, Brazil, as an officially secular state, should not suffer religious interference in the regulation of families' laws. That is not the case. As has been shown, there is strong interference by Christianity in the regulation of legal institutes.

2. In Brazil, the conjugal union with the intention of forming a family can take formally by marriage or by the stable union, and people can unite informally. Under Islamic law, marital union can only occur through marriage.

3. Among the purposes of Muslim marriage is to prevent sexual intercourse from occurring outside marriage, and even this conduct is prohibited, and in some countries criminalized. In Islam, sexuality is considered lawful only after marriage. In Brazil, there is no impediment for unmarried persons to have sexual relations outside of marriage, and safe sex is encouraged, since these practices are part of the daily life of young people, adults and elderly married or not. 
4. Brazil allows the formalization of the homoaffective union. Islamic law not only does not allow homoaffective marriage as it prohibits such practices, treating those relations as an illness or a detour. It should be noted that this prohibition stems from the interpretation of the Qur'an, since it does not use any terms that correspond to "homosexuals" or "homosexuality" throughout its text, nor does it provide for the death penalty as a sanction. However, seven states (Saudi Arabia, Iran, Sudan, Yemen, Mauritania and Nigeria) apply this penalty against homosexuals. ${ }^{50}$

5. Viewers to be strong gender issue linked to the unions, both in Islam and in Brazil. In relation to men, Islamic law gives women distinct rights, notably those related to marriage, divorce and inheritance, such as: polygamy is only permitted for men; the man may be married to a woman who is not a Muslim, otherwise the opposite is not allowed; immediate divorce is only allowed for men, including without cause. However, this non-equality of rights does not mean injustice to Islam. Under the Islamic perspective, there is equality. It is also important to emphasize that Islam is often used as a pretext to legitimize some local beliefs and traditions, ${ }^{51}$ but which are not foreseen in the Shari'a, such as the use of the veil (hijab) ${ }^{52.53}$

Brazilian legal system despite legally granting equal rights to women, prohibiting discrimination, in practice there is a strong gender inequality. Surely, the tendency to infidelity is historically masculine, so it is a matter of pride for man to maintain affective relationships with more than one woman. From this, a strengthening doctrine is that only when the "other" affirms that he does not know that his partner is in the "married" state, there is a recognition that he is in good faith and is admitted the recognition of stable union (called a putative stable union).

If the "other", however, asserts that he was aware of the double relationship, there is a characterization of bad faith and a bond is given by nonexistent, being at most recognized, in some cases, an entity with exclusively economic ends. Thus, when this division of property is extinguished, as a rule the property is in the name and in the hands of the man, it is up to the woman to prove that she contributed to the increase in her estate. If there has been no acquisition of property, nothing is conferred on the "concubine" (neither food nor any inheritance right). This is a conservative and discriminatory attitude toward women.

6. Endogenous polygamy (the one with the same family nucleus) is permitted in Islamic law and prohibited (also criminalized) in Brazil. As for exogenous polygamy (maintaining marital relations outside the familiar nucleus) in Islamic law, it is prohibited and, in some countries, criminalized (this does not mean that there is no extramarital affair). In Brazil, adultery ceased to be a crime, and in 2005, with the enactment of Law No. 11.106, which revoked article 240 of the Penal Code. As for the prohibition, there is controversy, since the Civil Code lists fidelity as the duty of both spouses, but the

\footnotetext{
50 About the theme check: REHMAN; POLYMENOPOULOU, 2013. The authors show that several passages of the Quran recognize homosexuality and celebrate sexual diversity, and that, therefore, it is inaccurate to suggest that there is a prohibition of homosexuality in Islam and advocate criminalization or the adoption of discrimination practices against sexual minorities.

51 Eltahawy (2015) attributes the misogyia of the Arab world to a "toxic mixture" of culture and religion. The author reinforces that is easy to accuse muslims of misogyia because they don't conceal it, but society as a whole perpetuates the oppression of women, as something cultural and not entirely linked to religion.

52 About the theme check: FERREIRA, 2013. The author says that the use of Islamic clothing should be analyzed from the perspective of the empowerment, identity and religiosity of Muslim women (free translation).

53 About the theme check: ARAFA; EL-ASHRY, 2017.
} 
Constitution is silent on the subject. Therefore, are those who think that it is a legal duty and there are those who think that they are a moral element (in the same way as monogamy). Despite the divergence, in Brazil the legal effects of polygamy (both endogenous and exogenous) have been recognized.

7. Finally, we note a contradictory situation: in spite of the clear permissibility of polygamy in Islam, its actual practice is small. Most Muslim men believe they cannot afford the expenses and responsibilities of more than one wife. In Brazil, the number of extraconjugal cases is enormous, so one can safely conclude that, contrary to the prevailing notion, Muslim men are strictly more monogamous than Brazilian men are.

Established these points of convergence and divergence, it is possible to calmly answer the question proposed in the title of the paper. Polygamy in Brazil is contrary to morality and not to the Law, since the Federal Constitution, as a rule, gives special protection to the family (whatever form it may have) and the State should only respect the choice of individuals. Moreover, the Constitution does not prescribe a principle of monogamy, so that any laws or interpretations that contradict this understanding are unconstitutional and have a strong subjective, moral character.

Already in Islamic law, law permits polygamy, and since it is part of religion itself, it is morally accepted. It does not therefore contradict neither the morality nor the Law. Within cultural and social issues, this practice is accepted.

\section{REFERENCES}

'ARAFA, Mohamed A.; EL-ASHRY, Ahmed. Gender Equality in the Arab and Muslim World: Whither Post-Revolutionary Egypt? In: Gender Equality in a Global Perspective. Routledge Advances in Management and Business Studies, Chapter 3, London \& New York. January 19, 2017. Available in: <https://ssrn.com/abstract=2901853>.

'ARAFA, Mohamed. Whither Egypt? Against Religious Fascism and Legal Authoritarianism: Pure Revolution, Popular Coup, or A Military Coup D'état?. Indiana International \& Comparative Law Review, v. 24, n. 4, 2014.

ABDAL-HAQQ, Irshad. Islamic law: an overview of its origins and elements. The journal of islamic law and culture, v. 7, n. 1, p. 28-82, 2002.

ALBUQUERQUE NETO, Carlos Cavalcanti de. Famílias simultâneas e concubinato adulterino. In: Anais do III Congresso Brasileiro de Direito de Família. Belo Horizonte: IBDFAM, 2002.

BADR, Gamal Moursi. Islamic Law: Its Relation to Other Legal Systems. The American Journal of Comparative Law, v. 26, n. 2, p. 187-198, 1978. 
BARBOSA, Leonardo Augusto de Andrade. História constitucional brasileira: mudança constitucional, autoritarismo e democracia no Brasil pós-1964. Brasília: Chamber of Deputies, 2012.

BASSIOUNI, M. Cherif; BADR, Gamal M. The Shari'ah: sources, interpretation, and rule-making. UCLA Journal of Islamic and Near Eastern Law, California, p. 1-31, Spring/Summer, 2002.

BRASIL. Constitution of the Federative Republic of Brasil. Available in: <http://www.planalto.gov.br/ccivil_03/constituicao/constituicaocompilado.htm>.

BRASIL. Decree-Law No. 2.848, of December 7, 1940. Penal code. Available in: <http://www.planalto.gov.br/ccivil_03/decreto-lei/del2848compilado.htm>.

BRASIL. Federal Supreme Court. ADI no. 4439. Available in: $<$ http://www.stf.jus.br/portal/geral/verPdfPaginado.asp?id=635016\&tipo=TP\&descricao=ADI\%2F4439>

BRASIL. Federal Supreme Court. Claim of non-compliance with a fundamental precept No. 54 . Minister Marco Aurélio Mello (rapporteur). Available in: $<$ http://redir.stf.jus.br/paginadorpub/paginador.jsp?docTP=TP\&doclD=3707334>.

BRASIL. Federal Supreme Court. Extraordinary resources No. 878.694 e 646.721. Rapporteur Minister Luís Roberto Barroso, judged on 10/5/2017.

BRASIL. Federal Supreme Court. Precedent No. 382. Available in: $<$ http://www.stf.jus.br/portal/jurisprudencia/menuSumarioSumulas.asp?sumula=2488>.

BRASIL. Federal Supreme Court. Precedent No. 35. Available in: $<$ http://www.stf.jus.br/portal/jurisprudencia/menuSumarioSumulas.asp?sumula=3074>.

BRASIL. Federal Supreme Court. Precedent No. 380. Available in: $<$ http://www.stf.jus.br/portal/jurisprudencia/menuSumarioSumulas.asp?sumula=2482>.

BRASIL. Law No. 10.406, of January 10, 2002. Establishes the Civil code. Available in: <http://www.planalto.gov.br/ccivil_03/Leis/2002//10406.htm>.

BRASIL. National Council of Justice. Cartórios são proibidos de fazer escrituras públicas de relações poliafetivas. Available in: <http://www.cnj.jus.br/noticias/cnj/87073-cartorios-sao-proibidos-de-fazerescrituras-publicas-de-relacoes-poliafetivas $>$.

BRASIL. National Council of Justice. Resolution No. 175, of May 14, 2013, that treats about the habilitation, the celebration of a civil marriage or the conversion of stable marriage into wedding 
between persons of same sex. Available in: <http://www.cnj.jus.br/busca-atosadm?documento $=2504>$.

BRASIL. Regional Court of Uniformization of the Federal Regional Court of the 4th Region, Incident of uniformity No. 5001063-10.2012.404.7112/RS. Rapporteur: Federal Judge Marcelo Malucelli, judged on: $2015 / 06 / 15$.

CARTA CAPITAL. STF debate descriminalização do aborto. Available in $<$ https://www.cartacapital.com.br/blogs/intervozes/stf-debate-descriminalizacao-do-aborto-e-midiasegue-sem-discutir-tema>.

CORREIA, Marcus Orione Gonçalves; CORREIA, Érica Paula Barcha. Curso de Direito da Seguridade Social. 6. ed. São Paulo: Saraiva, 2012.

DAL PIVA, Juliana. Rio registra primeira união estável realizada entre três mulheres. O Estado de São Paulo Journal, october 18, 2015. Available in: <https://brasil.estadao.com.br/noticias/rio-dejaneiro,rio-registra-primeira-uniao-estavel-entre-3-mulheres,1781538>.

Delas-IG. São Paulo é a cidade com mais casos extraconjugais do mundo. Available in: $<$ https://delas.ig.com.br/amoresexo/2017-07-21/sao-paulo-casos-extraconjugais.html>.

DIÁRIO CENTRO DO MUNDO. Pesquisadora cristã defende a descriminalização do aborto. Available in: <https://www.diariodocentrodomundo.com.br/pesquisadora-crista-defende-a-descriminalizacao-doaborto-no-stf/>.

DIAS, Maria Berenice. Adultério, bigamia e união estável: realidade e responsabilidade. Available in: $<\mathrm{http}: / /$ www.mariaberenice.com.br/manager/arq/(cod2_790)4_adulterio_bigamia_e_uniao_estavel_r ealidade_e_responsabilidade.pdf>.

DIAS, Maria Berenice. Casamento: nem direitos nem deveres, só afeto. Revista Ajuris, Porto Alegre v. 80, p. 205-210, dez. 2000.

DIAS, Maria Berenice. Manual de Direito das Famílias. 10. ed.rev. atual. e ampl. São Paulo: Revista dos Tribunais, 2015.

DIAS, Maria Berenice. Supremo acertou ao não diferenciar união estável de casamento. Consultor Jurídico Journal, 14 jun. 2017. Available in: <https://www.conjur.com.br/2017-jun-14/berenice-dias-stfacertou-igualar-uniao-estavel-casamento>. 
DIMOULIS, Dimitri. Objetivos e métodos do direito comparado e peculiaridades do direito constitucional comparado. Brazilian Journal of Constitutional Studies - RBEC, Belo Horizonte, Year 10, n. 35, p. 77-88, may/aug. 2016.

DIMOULIS, Dimitri. Positivismo jurídico. Col. Gilmar Mendes. Série 2. São Paulo: Método Publisher, 2006.

EGYPT. Constitution of the Arab Republic of Egypt. 2014. Available in: $<$ https://www.constituteproject.org/constitution/Egypt_2014.pdf>.

ELTAHAWY, Mona. Headscarves and Hymens. Why the Middle East Needs a Sexual Revolution? London: Weidenfeld \& Nicolson, 2015.

FERREIRA, Francirosy Campos Barbosa. Diálogos sobre o uso do véu (hijab): empoderamento, identidade e religiosidade. Perspectivas, São Paulo, v. 43, p. 183-198, jan./jun. 2013.

GADAMER, Hans-Georg. Verdade e método: traços fundamentais de uma hermenêutica filosófica. Flávio Paulo Meurer translation. 3. ed. Petrópolis: Vozes, 1997.

HAELI, Shahla. Law of Desire. Temporary marriage in Shi'a Iran. New York: Syracuse University Press, 2014.

HOLY BIBLE. Available in: <https://www.bibliaonline.com.br/acf/ef/5>. Acessed on: 10 aug. 2018.

HOUAISS, Antonio; Mauro de Salles. "Polygamy". Electronic dictionary Houaiss of the Portuguese language 3.0.

ISLAM RELIGION. Introdução à poligamia no Islã. 2010. Available in: $<$ https://www.islamreligion.com/pt/articles/325/introducao-a-poligamia-no-isla/>.

KREUZ, Letícia Regina Camargo. Laicidade "à brasileira" e a decisão do Supremo Tribunal Federal sobre ensino religioso confessional. In: Anais do XIII Simpósio Nacional de Direito Constitucional ABDConst, v. 1, 2018. Disponível em: <http://abdconst.com.br/6-anais-do-xiii-simposio>.

KREUZ, Letícia Regina Camargo. Domínio do corpo: o aborto entre leis e juízes. Curitiba: Íthala, 2018.

LEGRAND, Pierre. Foreign law as self-fashioning. JCL, vol. 12, n. 2, p. 6-44, 2012. 
LEICHTER, Alexandra. The effect of islamic family law on north american family law issues. 2009. Available

$<$ https://www.iafl.com/cms_media/files/the_effect_of_islamic_family_law_on_north_american_family_I aw_issues.pdf>.

LIPOVETSKY E SILVA, Nathália. Breve estudo sobre o Sistema jurídico islâmico. CAAP Journal, Belo Horizonte, n. 2, p. 49-73, jul./dic. 2009.

LÔBO, Paulo Luiz Netto. Entidades familiares constitucionalizadas: para além do numerus clausus. 2004. Available in: <http://www.ibdfam.org.br/_img/congressos/anais/193.pdf>.

NASSER, Salem Hikmat. Direito islâmico e direito internacional: os termos de uma relação. Direito GV Journal, São Paulo, v. 8, n. 2, p. 725-744, jul./dic, 2012.

NOGUEIRA, Gabriel. Positivismo Jurídico e a Teoria Geral do Direito na obra de Hans Kelsen. São Paulo: Revista das Tribunais, 2010.

OLIVEIRA, Manfredo Araújo. Reviravolta lingüístico-pragmática na filosofia contemporânea. São Paulo: Loyola, 1996.

PIANOVSKI, Carlos Eduardo. Famílias Simultâneas e monogamia. In: PEREIRA, Rodrigo da Cunha (Coord.). Família e dignidade humana: anais do $\mathrm{V}$ congresso brasileiro de direito de família. São Paulo: IOB Thomson, 2006. p. 193-221.

REHMAN, Javaid; POLYMENOPOULOU, Eleni. Is Green a Part of the Rainbow? Sharia, Homosexuality and LGBT Rights in the Muslim World. Fordham International Law Journal, New York, v. 37, n. 1,2013

SARMENTO, Daniel. O crucifixo nos Tribunais e a laicidade do Estado. Eletronic Journal PRPE, Recife, year $5, \quad$ may $2007 . \quad$ Available <http://www.prpe.mpf.mp.br/internet/index.php/internet/Revista-Eletronica/Revista-Eletronica/2007ano-5/(offset)/10>.

TADMOURI, Ghazi O; et. al. Consanguinity and reproductive health among Arabs. Reproductive Health, v. 6, n. 1, 2009. Available in: <https://reproductive-healthjournal.biomedcentral.com/track/pdf/10.1186/1742-4755-6-17>.

THE NOBLE QUR'AN. Available in: <https://quran.com/33/4-5>.

TURKEY. Constitution of the Republic of Turkey, 7 November 1982. Available in: $<$ http://www.refworld.org/docid/3ae6b5be0.html>. 
WORLD ATLAS. Islamic Countries in the World. Available in: $<$ https://www.worldatlas.com/articles/islamic-countries-in-the-world.html>.

Revista do Direito [ISSN 1982-9957]. Santa Cruz do Sul, n. 63, p. 26-48, jan. 2021. https://online.unisc.br/seer/index.php/direito/index 